\title{
Immunosenescence: More research is needed
}

Keywords: immunosenescence, aging, neutrophils, lymphocytes

\section{Opinion}

Around the world, the number of older people (age $\geq 60$ years) increased by 2.6 , from 759 million people in 2010 to 2 billion by $2050 .^{1}$ As aging is a process strongly associated with disease, this leads to health professionals to seek understanding of the clinical disorders that most affect the lives of the elderly. Recent research attempts to explain the high risk of infections in the elderly as a result of a process called immunosenescence, which is a state of gradual deterioration of the immune system caused by natural aging.

Immunosenescence, or immune aging, is a remodeling of the immune system, caused by natural human aging, which affects the innate and adaptive immune system. Aging is associated with the breakdown of skin, lung and gastrointestinal epithelial barriers, allowing the invasion of pathogenic bacteria by these tissues. Thus, the elderly are more susceptible to severe infectious diseases, however, why they are more vulnerable to such infections still need to be better understood..$^{1,2}$

Immunosenescence can affect both innate and adaptive immunity, and changes with aging in this highly complex system are associated with progressive decline in immune function with increased susceptibility to infections, increased autoantibodies, and reduced vaccine response. Thus, immunosenescence can alter the function of various cells of the immune system such as neutrophils, lymphocytes and regulatory $\mathrm{T}$ cells (Treg). ${ }^{3,4}$ Neutrophils are phagocytic cells that play an important role in the innate immune response against microorganisms, with the function of identifying, ingesting and destroying several types of pathogens, being the main type of mediator cell of acute inflammatory response to bacterial infections. ${ }^{5,6}$

The adaptive immune system promotes the specific immune response conducted by lymphocytes, which are classified into two large populations, T and B lymphocytes. ${ }^{7}$ Cellular immunity is mainly mediated by $\mathrm{T}$ lymphocytes which are divided into two subpopulations: the subpopulation that expresses the CD4 molecule ( $\mathrm{T}$ helper cells), whose function is to control the immune response; and the subpopulation that expresses the CD8 molecule (cytotoxic $\mathrm{T}$ cells) whose function is to destroy the target cells. ${ }^{6,7}$ The humoral response is mainly managed by B lymphocytes, with the production of specific antibodies. ${ }^{5,7}$ Treg cells are important for maintaining selftolerance, controlling autoimmunity and regulating $\mathrm{T}$ lymphocyte homeostasis, besides modulating diverse immune responses against infectious agents and tumor cells. ${ }^{8}$ As the exact changes occurring in
Volume 4 Issue 3 - 2017

\author{
Alessandra Barbosa Lopes,' Larissa Barbosa \\ Lopes, ${ }^{2}$ Zamir Calamita' \\ 'Marilia School of Medicine -FAMEMA, Brazil \\ ${ }^{2}$ University of São paulo, Brazil \\ Correspondence: Zamir Calamita, Discipline of Clinical \\ Immunopathology and Allergy, Marilia School of Medicine- \\ FAMEMA, Brazil, Email zcalamita@hotmail.com \\ Received: August 20, 2017| Published: December 15, 2017
}

the immune system remain unknown and therefore, further research is needed in the area investigating the aging of the immune system.

\section{Acknowledgements}

None.

\section{Conflict of interest}

The author declares no conflict of interest.

\section{References}

1. Dewan SK, Zheng S, Xia S, et al. Senescent remodeling of the immune system and its contribution to the predisposition of the elderly to infections. Chin Med J (Engl). 2012;125(18):3325-3331.

2. Silva FP, Zampieri FG, Barbeiro DF, et al. Septic shock in older people: a prospective cohort study. Immun Ageing. 2013;10(1):21.

3. Agondi RC, Rizzo LV, kalil J, et al. Imunossenescência. Rev bras Alerg Imunopatol. 2012;35(5):169-176.

4. Boraschi D, Italiani P. Immunosescence and vaccine failure in the elderly: Strategies for improving response. Immunol Lett. 2014;162(1 Pt B):346-353.

5. Janeway CA, Travers P, Walport M, et al. Imunobiologia: o sistema imune na saúde e na doença. Porto Alegre, Brazil: Springer; 2001.

6. Abbas AK, Lichtman AH. Imunologia Celular e Molecular. Netherlands; 2005.

7. Mota SMQ. Parametros de normalidade do Sistema imunológico no idoso em Fortaleza-Ceará [tese]. Fortaleza: Universidade Federal do Ceará, 2009. 74 p.

8. Simonetta F, Chiali A, Cordier C, et al. Increased CD127 expression on activated FOXP3+ $\mathrm{CD} 4+$ regulatory $\mathrm{T}$ cells. Eur J Immunol. 2010;40:2528-2538. 